Brestovci Shqipe Bajçinca, Morina Besnik, Berisha Mentor. Urban-rural differences of free activities in children of age 11-14. Journal of Education, Health and Sport. 2020;10(3):42-56. eISSN 2391-8306. DOI http://dx.doi.org/10.12775/JEHS.2020.10.03.004

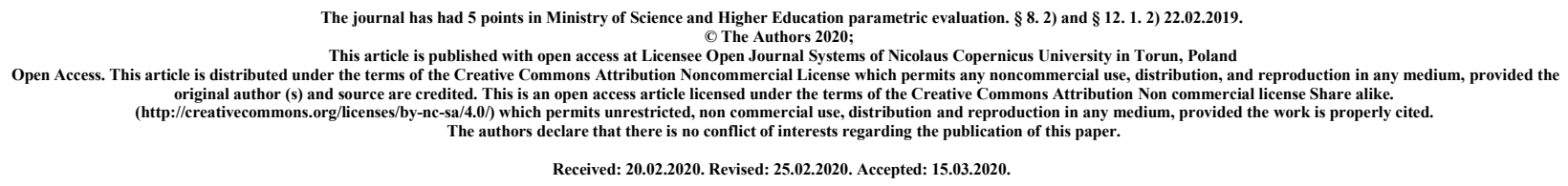

\title{
Urban-rural differences of free activities in children of age 11-14
}

\author{
Shqipe Bajçinca Brestovci*, Besnik Morina, Mentor Berisha
}

\author{
Faculty of Physical Education and Sport, University Hasan Prishtina, Pristina, Kosovo \\ *Corresponding Author Email: shqipe.bajcinca@uni-pr.edu
}

\begin{abstract}
Objectives: The problem of the research is to investigate the situation of free activities of primary school students in urban and rural areas in Kosovo. The subject of the research is male and female third level elementary school students (grades 6, 7, 8,9) in urban and rural areas. In accordance with the object and the problem defined in this research, the main purpose of the research is also defined. The main purpose of this research is to determine what children do during their free time, as well as to look at the differences between children in urban and rural areas.

Methods: The research was conducted in a sample consisting of 413 boys and girls (11 - 14) attending elementary school. The total sample includes 413 respondents, 202 boys and 211 girls. The sample is divided into the following sub-samples: 115 eleven year old male and female students, 144 twelve year old male and female students, 97 thirteen year old male and female students, 57 fourteen year old male and female students. The research material was collected in 2017. To assess what the students do more in their spare time a questionnaire called "My Lifestyle" was used.

Results: Research results show that the most frequent forms of leisure time spending are: listening to music, meeting friends, playing with friends, reading books and watching videos/TV. The obvious reason for this may be the lack of access to sports equipment and facilities.

Conclusion: This research shows that the level of wealthier (not very high both in households and in the whole country) can have an impact on the choice of activities undertaken by young people. Undoubtedly, social and cultural as well as traditional factors also have a great influence in the way of spending free time as can be seen in the case of this study.
\end{abstract}

Key words: leisure activities, leisure time, free time, lifestyle, social and cultural factors.

\section{Introduction}

Physical activity is a powerful marker of health status during childhood and adolescence. Physical activity is considered to be a key factor in the healthy physical and mental development of children; the rise and spread of obesity in children puts children at high risk of developing some chronic illnesses in later life. 
In recent years, several international organizations such as the American College of Sports Medicine (ACSM) have recommended that children should participate in physical activity $>60$ min daily in an organized manner, both at home and outside school. Children have the right to play and rest even in their free time. A meaningful time can be a support in the development of the child. Most children love to be with their friends during their free time. It is common to surf on the internet, watch TV and listen to music. Many engage in more organized activities (The child's leisure time) . Young people at this age often cause problems, are difficult to communicate with, and the phenomenon of "youth rebellion" can occur. During this time one can see that free physical activity depends, to a large extent, on a number of activities that go beyond the problems covered by the school curriculum but deal with the educational environment in which every student grows up. From the perspective of health needs, the most important part of this activity should be based on physical activity. It is known that such activities have a very positive impact on the development of biological characteristics (stimulate growth, strengthen the body, develop speed, endurance, concentration, improve reflexes) (Umiastowska, 1999), and in psycho-social problems (selfesteem, ability to self-control, ability to work with other people).

For the sake of clarity, we need first to clarify the term leisure. It was first defined during an international conference in 1956. As defined by the French sociologist (Dumazedier J, 1956), leisure means all activities undertaken by an individual for entertainment or self-development, voluntary participation in social life, and family responsibilities. This definition only considers adults. On the other hand, according to (Dąbrowski, 1966), youth leisure is the time that remains available to them after fulfilling their body's needs and performing homework and school assignments in which they can perform their activities according to their preferences, related to leisure, entertainment and pursuing their interests. According to the authors (Glapa, Bronikowski, Górka, \& Morina, 2013) the level of wealth (not so much of the family, but of the whole country) can influence the choice of activities undertaken by young people. Certainly the socio-cultural factors and the tradition of social life, which impose certain ways of spending leisure time.

To get a fuller picture of young people's behavior in the critical social, psychological and physical growth period, the research study will be conducted in two groups that include (rural and urban) locations in two Kosovo municipalities. Comparative studies are conducted in pedagogy to identify potential trends and development paths. So the first step in this case is to identify the current state of children's leisure activities at this age.

\section{Materials and Methods}

\subsection{Study design and subjects}

Data were collected through a questionnaire. A research tool used to assess students' lifestyles, a questionnaire called "My Lifestyle", designed by a team of European researchers [Telama R., Naul R., Nupponen H., Rychtecky A., Vuolle P., 2002]. The questionnaire was translated and adapted by a team of professional translators in collaboration with the Faculty of Physical Education and Sport, Prishtina. The research was conducted in the group of 413 children aged 11-14 years, out of which 208 students from urban areas and 205 students from rural areas. The research material was collected in 2017.

To assess the status of what students do best in their spare time we used a questionnaire called "My Lifestyle" which include following questions:

1. How do you spend your free time? (You can choose from three answers)

2. How many times during the last three months have you done physical activity in your spare time (for at least 30 minutes).

3. What forms of physical activity do you do during your free time?

4. I participate in various physical activities because ... (list three reasons at most)

5. I do physical activity leisure time with ...

6. I think I am .....

7. I evaluate my motor fitness as ...

8. Do your parents engage in any form of sports in their spare time (Mother-Father)?

\subsection{Statistical analysis}

Basic statistical parameters (descriptive analysis) were calculated for all the research results so that we could present the state of realization of the subject of leisure time of this research.

data processing will use the "Chi Square Test" which lets us know if two groups have very different opinions, which makes it a very useful statistic for survey research. 


\section{Results}

\subsection{Results of basic statistical parameters}

\section{Results of the question "How do you spend your leisure time?"}

Table 1. Results of the question How do you spend your leisure time?

\begin{tabular}{|l|r|r|r|}
\hline \multirow{2}{*}{} & \multicolumn{2}{|c|}{ Missing } & Valid N \\
\cline { 2 - 4 } & $\mathrm{N}$ & Percent & 3 \\
\hline I don't do anything & 410 & $99.3 \%$ & 5 \\
Play cards & 408 & $98.8 \%$ & 12 \\
Play music on instruments, & 401 & $97.1 \%$ & \\
sing in chorus & & & 13 \\
I go to the cinema, theater, & 400 & $96.9 \%$ & \\
concert & & & 14 \\
Hobby activities & 399 & $96.6 \%$ & 16 \\
I go to races as a spectator & 397 & $96.1 \%$ & 55 \\
I practice club sports in a & 358 & $86.7 \%$ & \\
Sports section & & & 58 \\
Family visits & 355 & $86.0 \%$ & 66 \\
Play computer games & 347 & $84.0 \%$ & 81 \\
I practice sports with friends & 332 & $80.4 \%$ & \\
on the sports field & & & 112 \\
I meet friends & 301 & $72.9 \%$ & 116 \\
Play with friends & 297 & $71.9 \%$ & 123 \\
I read books, newspapers & 290 & $70.2 \%$ & 189 \\
Watch TV, Video & 224 & $54.2 \%$ & 290 \\
I listen to music & 123 & $29.8 \%$ & \\
\hline
\end{tabular}

In this question, students were entitled to answer three alternatives on how they spend their free time. According to the table, the results show that only 3 students interviewed do nothing during their leisure time, 5 others play cards, 12 others stated that during their free time they play music on instruments or sing in chorus. 13 others stated that they go to cinema, theater, concert, 14 others stated that they do hobby activities, 16 others stated that they go to spectator competitions, 55 stated that during their leisure time they practice sports in a club, in a section of sports, 58 make family visits, 66 others said they play computer games, 81 respondents said they practice sports with friends in the sport, 112 stated they spend time with friends, 112 said they play with friends, 123 stated that they read books during their leisure time, 189 stated that they watched TV or video during their leisure time, while another 290 stated that they were listening to music during their leisure time. 
2. Question Results "How many times in the past three months have you been doing physical activity in your spare time (at least 30 minutes)?"

Table 2. Question Results - How many times in the past three months have you been doing physical activity in your spare time (at least 30 minutes)?"

\begin{tabular}{|l|r|r|r|r|}
\hline & Frequency & Percent & Valid Percent & $\begin{array}{c}\text { Cumulative } \\
\text { Percent }\end{array}$ \\
\hline Never & 4 & 1.0 & 1.0 & 1.0 \\
Less than once a week & 11 & 2.7 & 2.7 & 3.6 \\
Once a week & 28 & 6.8 & 6.8 & 10.4 \\
Twice a week & 100 & 24.2 & 24.2 & 34.6 \\
Valid & 120 & 29.1 & 29.1 & 63.7 \\
Three times a week & 56 & 13.6 & 13.6 & 77.2 \\
Five times a week & 94 & 22.8 & 22.8 & 100.0 \\
Every day & 413 & 100.0 & 100.0 & \\
Total & &
\end{tabular}

Four respondents $(1 \%)$ stated that during the past three months, they had never undertaken any physical activity in their spare time. 11 others $(2.7 \%)$ stated that they have taken up physical activity less than once a week, 28 others $(6.8 \%)$ once a week, $100(24.2 \%)$ of respondents stated that twice weeks of physical activity, 120 of the respondents $(29.1 \%)$ stated that they had taken physical activity three times a week, $56(13.6 \%)$ five times a week, $94(22.8 \%)$ of the respondents stated that they had taken daily activity physical.

\section{Question Results: What forms of physical activity do you do during your free time?}

Table 3. Question Results - What forms of physical activity do you take up during your free time?

\begin{tabular}{|c|c|c|c|c|c|}
\hline & & Frequency & Percent & Valid Percent & $\begin{array}{c}\text { Cumulative } \\
\text { Percent }\end{array}$ \\
\hline \multicolumn{6}{|c|}{ 1. Running } \\
\hline Valid & $\begin{array}{l}\text { Sometimes } \\
\text { Never } \\
\text { Often }\end{array}$ & $\begin{array}{c}201 \\
1 \\
211\end{array}$ & $\begin{array}{c}48.7 \\
.2 \\
51.1\end{array}$ & $\begin{array}{c}48.7 \\
.2 \\
51.1\end{array}$ & $\begin{array}{c}48.7 \\
48.9 \\
100.0\end{array}$ \\
\hline \multicolumn{6}{|c|}{ 2. Swimming } \\
\hline Valid & $\begin{array}{c}\text { Sometimes } \\
\text { Never } \\
\text { Often }\end{array}$ & $\begin{array}{c}260 \\
141 \\
12\end{array}$ & $\begin{array}{l}63.0 \\
34.1 \\
2.9\end{array}$ & $\begin{array}{l}63.0 \\
34.1 \\
2.9\end{array}$ & $\begin{array}{l}63.0 \\
97.1 \\
100.0\end{array}$ \\
\hline \multicolumn{6}{|c|}{ 3. Biking } \\
\hline Valid & $\begin{array}{l}\text { Sometimes } \\
\text { Never } \\
\text { Often }\end{array}$ & $\begin{array}{c}166 \\
41 \\
206\end{array}$ & $\begin{array}{c}40.2 \\
9.9 \\
49.9\end{array}$ & $\begin{array}{c}40.2 \\
9.9 \\
49.9\end{array}$ & $\begin{array}{c}40.2 \\
50.1 \\
100.0\end{array}$ \\
\hline 4. & Basketball & & & & \\
\hline Valid & $\begin{array}{l}\text { Sometimes } \\
\text { Never } \\
\text { Often }\end{array}$ & $\begin{array}{r}230 \\
107 \\
76\end{array}$ & $\begin{array}{l}55.7 \\
25.9 \\
18.4\end{array}$ & $\begin{array}{l}55.7 \\
25.9 \\
18.4\end{array}$ & $\begin{array}{r}55.7 \\
81.6 \\
100.0\end{array}$ \\
\hline
\end{tabular}




\begin{tabular}{|c|c|c|c|c|c|}
\hline 5. & Volleyball & & & & \\
\hline \multirow{3}{*}{ Valid } & Sometimes & 229 & 55.4 & 55.4 & 55.4 \\
\hline & Never & 107 & 25.9 & 25.9 & 81.4 \\
\hline & Often & 77 & 18.6 & 18.6 & 100.0 \\
\hline \multicolumn{6}{|c|}{ 6. $\quad$ Football } \\
\hline \multirow{3}{*}{ Valid } & Sometimes & 122 & 29.5 & 29.5 & 29.5 \\
\hline & Never & 97 & 23.5 & 23.5 & 53.0 \\
\hline & Often & 194 & 47.0 & 47.0 & 100.0 \\
\hline \multicolumn{6}{|c|}{ 7. Handball } \\
\hline \multirow{3}{*}{ Valid } & Sometimes & 179 & 43.3 & 43.3 & 43.3 \\
\hline & Never & 181 & 43.8 & 43.8 & 87.2 \\
\hline & Often & 53 & 12.8 & 12.8 & 100.0 \\
\hline \multicolumn{6}{|c|}{ 8. $\quad$ Aerobic } \\
\hline \multirow{3}{*}{ Valid } & Sometimes & 55 & 13.3 & 13.3 & 13.3 \\
\hline & Never & 347 & 84.0 & 84.0 & 97.3 \\
\hline & Often & 11 & 2.7 & 2.7 & 100.0 \\
\hline \multicolumn{6}{|c|}{$\begin{array}{ll}\text { 9. } & \begin{array}{l}\text { Weight } \\
\text { lifting }\end{array} \\
\end{array}$} \\
\hline \multirow{3}{*}{ Valid } & Sometimes & 113 & 27.4 & 27.4 & 27.4 \\
\hline & Never & 285 & 69.0 & 69.0 & 96.4 \\
\hline & Often & 15 & 3.6 & 3.6 & 100.0 \\
\hline
\end{tabular}

In the running activity, the results show that $48.7 \%$ of the respondents declared that they sometimes run during their leisure time, $0.2 \%$ declared that they never run during their leisure time, while $51.1 \%$ declared that they often run during their leisure time. jogging, as a physical activity.

Regarding swimming, as a physical activity, the results show that $63 \%$ of the respondents declared that they sometimes do swimming during their leisure time, $34.1 \%$ declared that they never do swimming during their leisure time, while $2.9 \%$ stated that they often do during leisure time they are engaged in swimming, as a physical activity.

The results show that $40.2 \%$ of the respondents occasionally ride a bike during their leisure time, $9.9 \%$ stated that they never ride a bicycle during their leisure time, while $49.9 \%$ stated that they often ride a bike during their leisure time.

Regarding the game of basketball as a physical activity, the results show that $55.7 \%$ of the respondents declared that they sometimes play basketball during their leisure time, $25.9 \%$ stated that they never play basketball during their leisure time, while $18.4 \%$ stated that they are often playing basketball during their free time.

Regarding volleyball as a physical activity, the results show that $55.4 \%$ of respondents stated that they sometimes play volleyball, $25.9 \%$ said they never play volleyball, while $18.6 \%$ stated that they play volleyball often during their free time.

Regarding the game of football as a physical activity, the results show that $29.5 \%$ of the respondents stated that they sometimes play football during their leisure time, $23.5 \%$ stated that they never play football during their leisure time, while $47 \%$ declared that they play often football during their free time.

Regarding handball as a physical activity, the results show that $43.3 \%$ of the respondents stated that they sometimes play handball, $43.8 \%$ stated that they never play handball, while $12.8 \%$ stated that they often they play handball during their free time.

Research results show that $13.3 \%$ of respondents sometimes use aerobic leisure, $84 \%$ never engage in aerobic leisure, while $2.7 \%$ stated that they often do aerobic leisure.

Nearly $27.4 \%$ of the respondents stated that during leisure time they sometimes engage in weight gain as a physical activity, $69 \%$ stated that they never engage in this activity while $3.6 \%$ stated that they often do weight gain. 
4. The results of the question "I participate in various physical activities because ...?"

Table 4. Question Results - "I participate in various physical activities because ...?"

\begin{tabular}{|l|r|r|r|}
\hline \multirow{2}{*}{} & \multicolumn{2}{|c|}{ Missing } & Valid N \\
\cline { 2 - 3 } & $\mathrm{N}$ & Percent & \\
\hline For financial gain & 409 & $99.0 \%$ & 4 \\
The family encourages me & 407 & $98.5 \%$ & 6 \\
I can fulfill my sporting & 389 & $94.2 \%$ & 24 \\
ambitions & & & \\
Meet new people & 383 & $92.7 \%$ & 30 \\
To meet friends & 381 & $92.3 \%$ & 32 \\
For better grade in PE & 372 & $90.1 \%$ & 41 \\
To look good / beautiful & 360 & $87.2 \%$ & 53 \\
For a sports career & 308 & $74.6 \%$ & 105 \\
For relaxation & 271 & $65.6 \%$ & 142 \\
I like competitions & 268 & $64.9 \%$ & 145 \\
For fun & 235 & $56.9 \%$ & 178 \\
For good physical condition & 204 & $49.4 \%$ & 209 \\
For health & 152 & $36.8 \%$ & 261 \\
\hline
\end{tabular}

Respondents to this question were entitled to answer with 3 different alternatives. According to the tabular data, it turns out that, 4 respondents stated that they are engaged in various physical activities for financial gain, 6 others stated that they are engaged in different activities because the family is what encourages them, 24 others stated that they engage in physical activity. different physical because they can fulfill their sporting ambitions, 30 stated that the reason is to meet young people, 32 deal to meet friends, 41 stated that they engage in physical activity for a better grade in EF, 53 others stated that they deal with AF for good / beautiful looks, 105 said they care for sports careers, 142 others for relaxation, 145 because they like racing, 178 respondents stated they enjoy AF for fun, 209 others for good physical fitness courses, 261 respondents stated that they deal with AF for health reasons.

\section{Question results: "I do leisure time physical activity with ..?"}

Table 5. Question results - "I do leisure activities with ..?"

\begin{tabular}{|l|r|r|r|r|}
\hline & Frequency & Percent & Valid Percent & $\begin{array}{c}\text { Cumulative } \\
\text { Percent }\end{array}$ \\
\hline With my parents & 14 & 3.4 & 3.4 & 3.4 \\
With my siblings & 73 & 17.7 & 17.7 & 21.1 \\
Valid & 292 & 70.7 & 70.7 & 91.8 \\
With friends & 32 & 7.7 & 7.7 & 99.5 \\
Alone & 2 & .5 & .5 & 100.0 \\
With others & 413 & 100.0 & 100.0 & \\
Total &
\end{tabular}

Approximately $3.4 \%$ of respondents stated that they engage in leisure time with parents, $17.7 \%$ with siblings, $70.7 \%$ with friends, $7.7 \%$ with courses themselves, $0.5 \%$ with others. 
6. Question results: "I think I'm ..?"

Table 6. Question results: "I think I'm ..?"

\begin{tabular}{|c|c|c|c|c|c|}
\hline & & Frequency & Percent & Valid Percent & $\begin{array}{c}\text { Cumulative } \\
\text { Percent }\end{array}$ \\
\hline \multirow{5}{*}{ Valid } & Very healthy & 123 & 29.8 & 29.8 & 29.8 \\
\hline & Healthy & 244 & 59.1 & 59.1 & 88.9 \\
\hline & Unhealthy & 2 & .5 & .5 & 89.3 \\
\hline & I can't assess my health & 44 & 10.7 & 10.7 & 100.0 \\
\hline & Total & 413 & 100.0 & 100.0 & \\
\hline
\end{tabular}

When asked how respondents think about themselves about health, $29.8 \%$ stated that they are very healthy, $59.1 \%$ thought they were healthy, $0.5 \%$ thought they were ill, $10.7 \%$ stated that they could not assess their health on their own.

7. Question results: "I assess my motor fitness as ..."?

Table 7. Question results: "I assess my motor fitness as ..."?

\begin{tabular}{|c|c|c|c|c|c|}
\hline & & Frequency & Percent & Valid Percent & $\begin{array}{c}\text { Cumulative } \\
\text { Percent }\end{array}$ \\
\hline \multirow{6}{*}{ Valid } & Extraordinary & 31 & 7.5 & 7.5 & 7.5 \\
\hline & Very good & 227 & 55.0 & 55.0 & 62.5 \\
\hline & Good & 114 & 27.6 & 27.6 & 90.1 \\
\hline & Acceptable & 40 & 9.7 & 9.7 & 99.8 \\
\hline & $\mathrm{Bad}$ & 1 & .2 & .2 & 100.0 \\
\hline & Total & 413 & 100.0 & 100.0 & \\
\hline
\end{tabular}

Nearly $7.5 \%$ of the respondents stated that they rate their motor fitness as exceptional, $55 \%$ as very good, $27.6 \%$ rated their motor fitness as good, $9.7 \%$ as satisfactory while $0.2 \%$ rated it as bad for their fitness. motor.

8. Result of the question: "Your parents, do they play any form of sport in their spare time?" (Mom - Dad)

Table 8. Result of the question: "Your parents, do they play any form of sport in their spare time?" (Mom - Dad)

\begin{tabular}{|l|c|c|c|c|}
\hline & Frequency & Percent & Valid Percent & $\begin{array}{c}\text { Cumulative } \\
\text { Percent }\end{array}$ \\
\hline & Mom - Dad & Mom - Dad & Mom - Dad & Mom - Dad \\
\hline They don't & $159-59$ & $38.5-14.3$ & $38.5-14.3$ & $38.5-14.3$ \\
Sometimes & $199-221$ & $48.2-53.5$ & $48.2-53.5$ & $86.7-68.0$ \\
Regularly & $39-113$ & $9.4-27.4$ & $9.4-27.4$ & $96.1-95.4$ \\
I don't know & $16-19$ & $3.9-4.6$ & $3.9-4.6$ & $100-100$ \\
Total & $413-412$ & $100-100$ & $100-100$ & \\
\hline
\end{tabular}

Nearly $38.5 \%$ of respondents stated that their mother never engaged in sports, $48.2 \%$ stated that she sometimes does, $9.4 \%$ stated that she regularly does, $3.9 \%$ stated that they did not know if their mother was engaged in physical activity or not. 
On the other hand, $14.3 \%$ of the respondents stated that their father never engaged in sports, $53.6 \%$ stated that he sometimes does, $27.4 \%$ stated that he regularly does, $4.6 \%$ stated that they do not know whether their father is engaged in physical activity or not.

\subsection{Hypothesis testing results}

I used the Chi-Square Test to test the hypotheses. Based on the subject matter, the research problem and the purpose of the research, but also on the experience of previous research, the following hypotheses were tested during the research:

\section{H: There is no statistically significant difference between children's leisure activities in urban and rural areas.}

H1: There is a statistically significant difference between children's leisure activities in urban and rural areas.

To validate the hypothesis of whether there is or is no statistically significant difference between children's free activities in urban and rural areas, I analyzed the hypothesis through the Chi-Square Test. This test included the place of residence of the respondents as well as the forms of physical activity undertaken by the respondents in both areas.

This testing was done for each individual activity that the respondents dealt with, and included 413 respondents (Table 9).

Table.9. Case Processing Summary

\begin{tabular}{|l|r|r|r|r|r|r|}
\hline \multirow{2}{*}{ Cases } & \multicolumn{2}{c|}{ Valid } & \multicolumn{3}{c|}{ Missing } & \multicolumn{2}{c|}{ Total } \\
\cline { 2 - 6 } & $\mathrm{N}$ & Percent & $\mathrm{N}$ & Percent & N & Percent \\
\hline 1. Running & 413 & $100.0 \%$ & 0 & $0.0 \%$ & 413 & $0.0 \%$ \\
\hline 2. Swimming & 413 & $100.0 \%$ & 0 & $0.0 \%$ & 413 & $0.0 \%$ \\
\hline 3. Biking & 413 & $100.0 \%$ & 0 & $0.0 \%$ & 413 & $0.0 \%$ \\
\hline 4. Basketball & 413 & $100.0 \%$ & 0 & $0.0 \%$ & 413 & $0.0 \%$ \\
\hline 5. Volleyball & 413 & $100.0 \%$ & 0 & $0.0 \%$ & 413 & $0.0 \%$ \\
\hline 6. Football & 413 & $100.0 \%$ & 0 & $0.0 \%$ & 413 & $0.0 \%$ \\
\hline 7. Handball & 413 & $100.0 \%$ & 0 & $0.0 \%$ & 413 & $0.0 \%$ \\
\hline 8. Aerobic & 413 & $100.0 \%$ & 0 & $0.0 \%$ & 413 & $0.0 \%$ \\
\hline 9. Weight lifting & 413 & $100.0 \%$ & 0 & $0.0 \%$ & 413 & $0.0 \%$ \\
\hline
\end{tabular}


Table.10. Residence * Running Crosstabulation

\begin{tabular}{|c|c|c|c|c|c|c|}
\hline & \multicolumn{3}{|c|}{ Running } & \multirow[t]{2}{*}{ Total } \\
\hline & & & Sometimes & Never & Often & \\
\hline \multirow{4}{*}{ Residence } & & Count & 116 & 0 & 92 & 208 \\
\hline & & Expected Count & 101.2 & .5 & 106.3 & 208.0 \\
\hline & \multirow{2}{*}{ Rural } & Count & 85 & 1 & 119 & 205 \\
\hline & & Expected Count & 99.8 & .5 & 104.7 & 205.0 \\
\hline \multirow{2}{*}{ Total } & & Count & 201 & 1 & 211 & 413 \\
\hline & & Expected Count & 201.0 & 1.0 & 211.0 & 413.0 \\
\hline \multicolumn{7}{|c|}{ Chi-Square Tests } \\
\hline & & & Value & df & \multicolumn{2}{|c|}{ Asymp. Sig. (2-sided) } \\
\hline \multirow{4}{*}{\multicolumn{3}{|c|}{$\begin{array}{l}\text { Pearson Chi-Square } \\
\text { Likelihood Ratio } \\
\text { Linear-by-Linear Association } \\
\mathrm{N} \text { of Valid Cases }\end{array}$}} & $9.215^{\mathrm{a}}$ & 2 & \multirow{4}{*}{\multicolumn{2}{|c|}{$\begin{array}{l}.010 \\
.008 \\
.004\end{array}$}} \\
\hline & & & 9.629 & 2 & & \\
\hline & & & 8.171 & 1 & & \\
\hline & & & 413 & & & \\
\hline
\end{tabular}

a. 2 cells $(33.3 \%)$ have expected count less than 5 . The minimum expected count is .50 .

Based on the results of the analysis, where the Chi-Square Test was used, we can see that the 2-sided significance column reported in the last column and the corresponding Pearson Chi-Square row, is smaller by $5 \%$ in significance level than the value $\mathrm{p}-0.05$, and in this case we reject the 0 hypothesis and accept the alternative. So, we conclude that there is a statistically significant difference of this activity of children in urban and rural areas.

Table.11. Residence * Swimming Crosstabulation

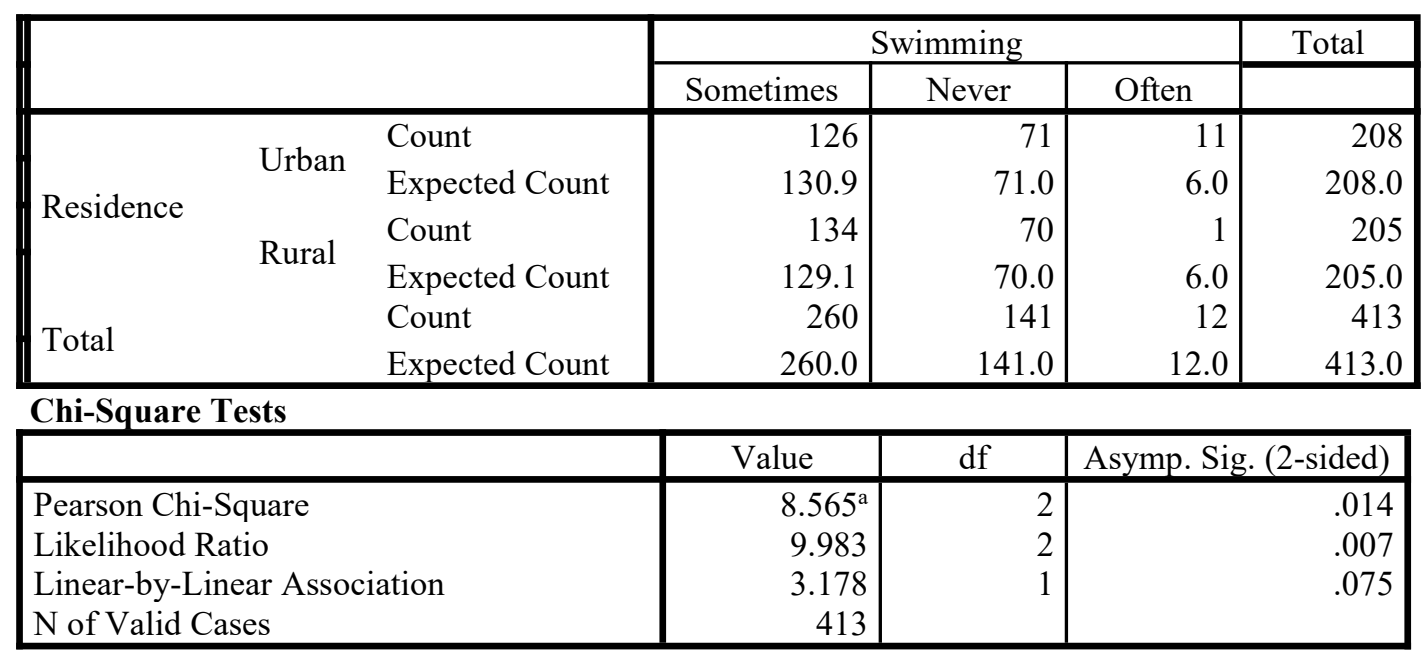

a. $\quad 0$ cells $(0.0 \%)$ have expected count less than 5 . The minimum expected count is 5.96 .

Comparison between residence and swimming as a leisure-time physical activity, in the table above, shows that based on the 2-sided significance column reported in the last column and the corresponding row at Pearson ChiSquare, significance level is $5 \%$ less than $\mathrm{p}-0.05$, in which case we reject the 0 hypothesis and accept the alternative. Thus, we find that there is a statistically significant difference in this activity of children in urban and rural areas. 
Table.12. Residence * Biking Crosstabulation

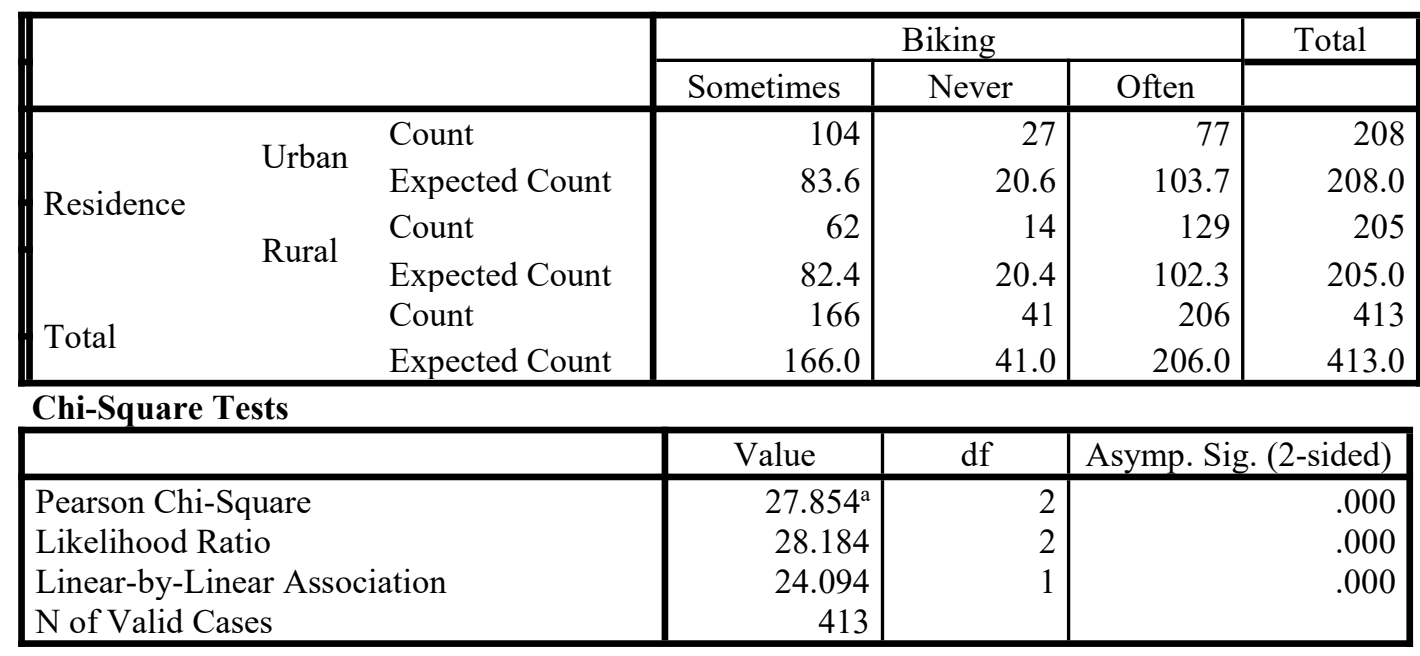

a. $\quad 0$ cells $(0.0 \%)$ have expected count less than 5 . The minimum expected count is 20.35 .

Based on the results of the analysis, where the Chi-Square Test was used, we can see that the 2-sided significance column reported in the last column and the corresponding Pearson Chi-Square row, is smaller by $5 \%$ in significance level than the value $\mathrm{p}-0.05$, and in this case we reject the 0 hypothesis and accept the alternative. So, we conclude that there is a statistically significant difference of this activity of children in urban and rural areas.

Table.13. Residence * Basketball Crosstabulation

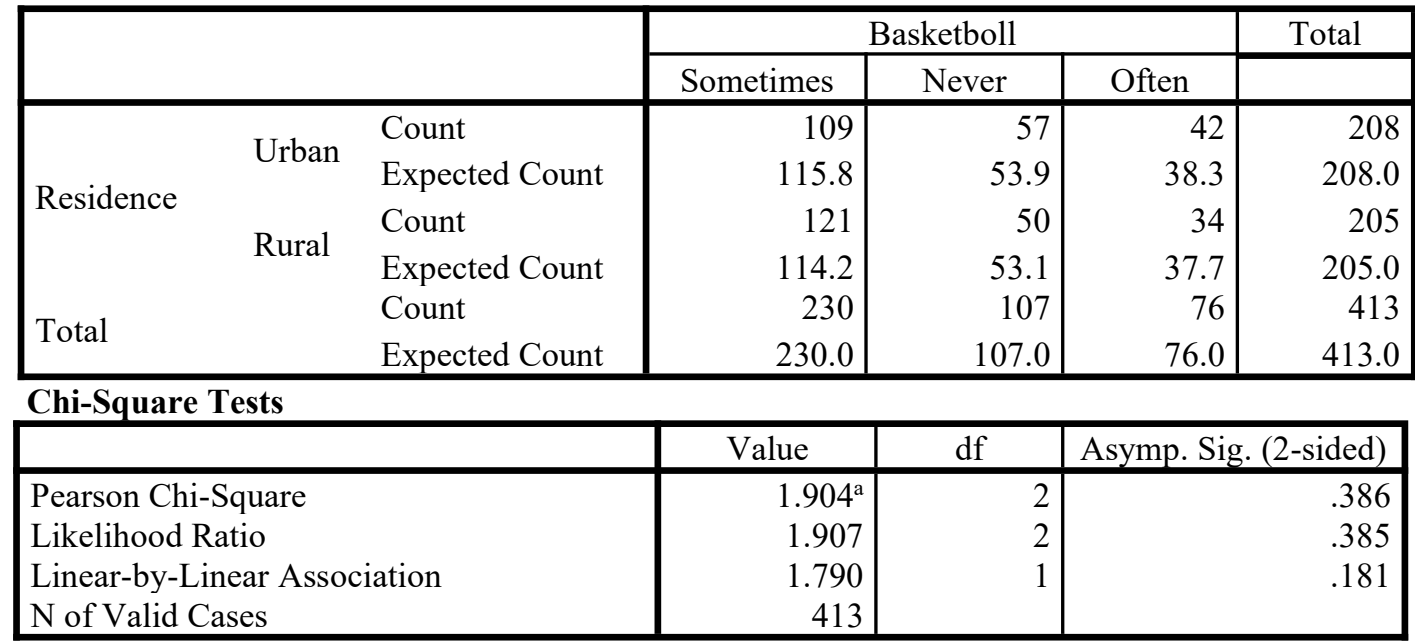

a. 0 cells $(0.0 \%)$ have expected count less than 5 . The minimum expected count is 37.72 .

Results from the 2-sided significance column reported in the last column and the corresponding row at Pearson ChiSquare, the value for $5 \%$ in significance level is greater than the value $\mathrm{p}-0.05$, and in this case we accept the 0 hypothesis and reject the alternative. So, we conclude that there is a statistically no significant difference of basketball as activity of children in urban and rural areas. 
Table.14. Residence * Volleyball Cross-tabulation

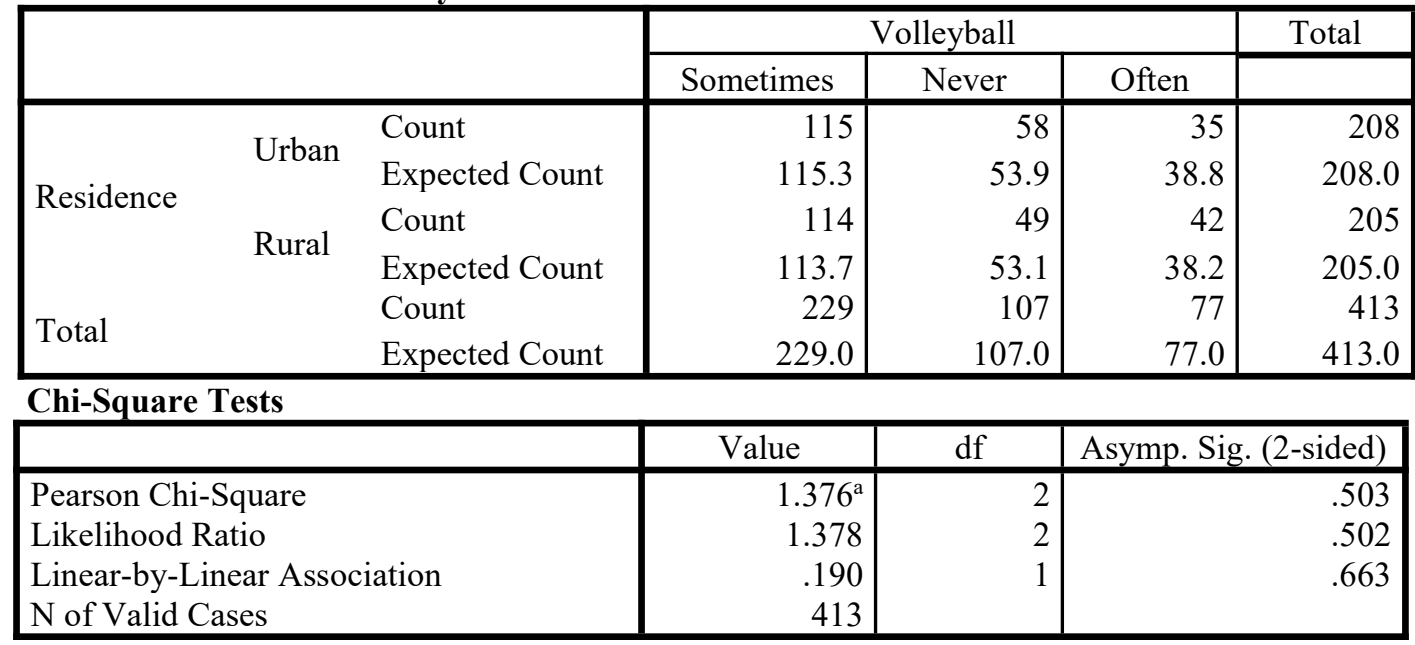

a. 0 cells $(0.0 \%)$ have expected count less than 5 . The minimum expected count is 38.22 .

Results from the 2-sided significance column reported in the last column and the corresponding row at Pearson ChiSquare, the value for $5 \%$ in significance level is greater than the value $p-0.05$, and in this case we accept the 0 hypothesis and reject the alternative. So, we conclude that there is a statistically no significant difference of Volleyball as activity of children in urban and rural areas.

Table.15. Residence * Football Crosstabulation

\begin{tabular}{|c|c|c|c|c|c|c|c|}
\hline & \multicolumn{4}{|c|}{ Football } & \multirow[t]{2}{*}{ Total } \\
\hline & & & Sometimes & Never & Often & 31.0 & \\
\hline \multirow{4}{*}{ Residence } & Juh & Count & 55 & 76 & 77 & 0 & 208 \\
\hline & Urban & Expected Count & 61.4 & 48.9 & 97.2 & .5 & 208.0 \\
\hline & Du & Count & 67 & 21 & 116 & 1 & 205 \\
\hline & Kural & Expected Count & 60.6 & 48.1 & 95.8 & .5 & 205.0 \\
\hline \multirow{2}{*}{ Total } & & Count & 122 & 97 & 193 & 1 & 413 \\
\hline & & Expected Count & 122.0 & 97.0 & 193.0 & 1.0 & 413.0 \\
\hline \multicolumn{8}{|c|}{ Chi-Square Tests } \\
\hline & & & Value & $\mathrm{df}$ & \multicolumn{3}{|c|}{ Asymp. Sig. (2-sided) } \\
\hline \multirow{4}{*}{\multicolumn{3}{|c|}{$\begin{array}{l}\text { Pearson Chi-Square } \\
\text { Likelihood Ratio } \\
\text { Linear-by-Linear Association } \\
\mathrm{N} \text { of Valid Cases }\end{array}$}} & $41.227^{\mathrm{a}}$ & 3 & & & .000 \\
\hline & & & 43.600 & 3 & & & .000 \\
\hline & & & 2.836 & 1 & & & .092 \\
\hline & & & 413 & & & & \\
\hline
\end{tabular}

a. 2 cells $(25.0 \%)$ have expected count less than 5 . The minimum expected count is .50 .

Based on the results of the analysis, where the Chi-Square Test was used, we can see that the 2-sided significance column reported in the last column and the corresponding Pearson Chi-Square row, is smaller by 5\% in significance level than the value $\mathrm{p}-0.05$, and in this case we reject the 0 hypothesis and accept the alternative. So, we conclude that there is a statistically significant difference of this activity (soccer) of children in urban and rural areas. 
Table.16. Residence * Handball Crosstabulation

\begin{tabular}{|c|c|c|c|c|c|c|}
\hline & & & \multicolumn{3}{|c|}{ Handball } & \multirow{2}{*}{ Total } \\
\hline & & & Sometimes & Never & Often & \\
\hline \multirow{4}{*}{ Residence } & \multirow{2}{*}{ Urban } & Count & & 141 & 6 & 208 \\
\hline & & Expected Count & 90.2 & 91.2 & 26.7 & 208.0 \\
\hline & \multirow{3}{*}{ Rural } & Count & 118 & 40 & 47 & 205 \\
\hline & & Expected Count & 88.8 & 89.8 & 26.3 & 205.0 \\
\hline \multirow{2}{*}{ Total } & & Count & 179 & 181 & 53 & 413 \\
\hline & & Expected Count & 179.0 & 181.0 & 53.0 & 413.0 \\
\hline \multicolumn{7}{|c|}{ Chi-Square Tests } \\
\hline & & & Value & df & \multicolumn{2}{|c|}{ Asymp. Sig. (2-sided) } \\
\hline \multicolumn{3}{|c|}{$\begin{array}{l}\text { Pearson Chi-Square } \\
\text { Likelihood Ratio } \\
\text { Linear-by-Linear Association } \\
\mathrm{N} \text { of Valid Cases }\end{array}$} & $\begin{array}{r}106.211^{\mathrm{a}} \\
114.211 \\
1.475 \\
413\end{array}$ & $\begin{array}{l}2 \\
2 \\
1\end{array}$ & \multicolumn{2}{|c|}{$\begin{array}{r}.000 \\
.000 \\
.225 \\
\end{array}$} \\
\hline
\end{tabular}

a. 0 cells $(0.0 \%)$ have expected count less than 5 . The minimum expected count is 26.31 .

Results from the 2-sided significance column reported in the last column and the corresponding row at Pearson ChiSquare, the value for $5 \%$ in significance level is greater than the value $\mathrm{p}-0.05$, and in this case we reject the 0 hypothesis and accept the alternative. So, we conclude that there is a statistically a significant difference of Handball as activity of children in urban and rural areas.

Table.17. Residence * Aerobic Crosstabulation

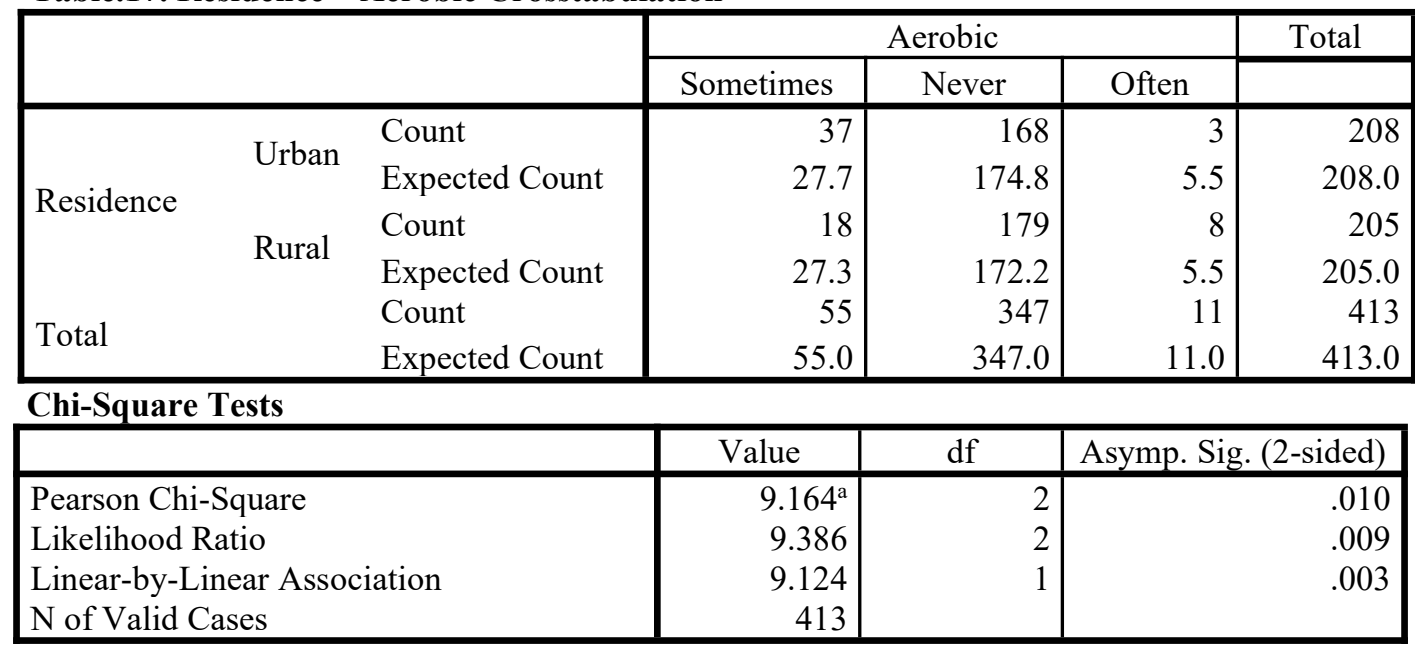

a. 0 cells $(0.0 \%)$ have expected count less than 5 . The minimum expected count is 5.46 .

In this case also, based on the results from the 2-sided significance column reported in the last column and the corresponding row at Pearson Chi- Square, for the 5\% significance level, the value is less than $\mathrm{p}-0.05$, therefore in this case we reject the 0 hypothesis and accept the alternative. Thus, we conclude that there is a statistically significant difference between residence and aerobic as physical activity during leisure time in urban and rural areas. 
Table.18. Residence * Weight lifting Crosstabulation

\begin{tabular}{|c|c|c|c|c|c|c|}
\hline & & & \multicolumn{3}{|c|}{ Weight lifting } & \multirow[t]{2}{*}{ Total } \\
\hline & & & Sometimes & Never & Often & \\
\hline \multirow{5}{*}{ Residence } & \multirow{2}{*}{ Urban } & Count & 69 & 128 & 11 & 208 \\
\hline & & Expected Count & 56.9 & 143.5 & 7.6 & 208.0 \\
\hline & \multirow{2}{*}{ Rural } & Count & 44 & 157 & 4 & 205 \\
\hline & & Expected Count & 56.1 & 141.5 & 7.4 & 205.0 \\
\hline & & Count & 113 & 285 & 15 & 413 \\
\hline Total & & Expected Count & 113.0 & 285.0 & 15.0 & 413.0 \\
\hline \multicolumn{7}{|c|}{ Chi-Square Tests } \\
\hline & & & Value & $\mathrm{df}$ & \\
\hline \multirow{4}{*}{\multicolumn{3}{|c|}{$\begin{array}{l}\text { Pearson Chi-Square } \\
\text { Likelihood Ratio } \\
\text { Linear-by-Linear Association } \\
\text { N of Valid Cases }\end{array}$}} & $11.727^{\mathrm{a}}$ & 2 & \multicolumn{2}{|c|}{$\begin{array}{r}\text { Asymp. sig. (2-sided) } \\
003\end{array}$} \\
\hline & & & 11.908 & 2 & \multicolumn{2}{|r|}{.003} \\
\hline & & & 2.847 & 1 & \multicolumn{2}{|r|}{.092} \\
\hline & & & 413 & & & \\
\hline
\end{tabular}

a. 0 cells $(0.0 \%)$ have expected count less than 5 . The minimum expected count is 7.45 .

Results from the 2-sided signification column reported in the last column and corresponding line at Pearson ChiSquare, for $5 \%$ level of significance, the value is less than $\mathrm{p}-0.05$, and in this case we reject the 0 hypotheses and we accept the alternative. Thus, we conclude that there is a statistically significant difference between residence and weight lifting as physical activity during leisure time in urban and rural areas.

\section{Discussion}

Leisure can be said to be one of the biggest problems in our Kosovar society. Young people find it difficult in their free time to engage in physical activity as much as possible, because in our country today in the electronic market children can find attractive electronic equipment from different companies that create a competition in the midst of bringing in new electronics, as well as providing supportive equipment such as ultra-chairs suitable for enticing young people to sell their products as much as possible. Therefore in this case parents can play a very important role for their children by trying to get as much free sports activities as possible to be a good overview for their children, so how to spend their leisure time, as much as possible with leisure sports activities, away from various electronic devices that directly affect the health of their children as a result of not engaging in various sports activities. Lifestyle is the image of the functioning of the individual or group (Nowak-Starz G, 2008). The process of forming a particular lifestyle goes hand in hand with educational activity, but becomes more important in adolescence. An individual's lifestyle can affect the strengthening of his or her health potential, or worse. That is why we can talk about its pro - health or anti - health character. The information we have collected during this research has made it possible to determine leisure time, frequency of physical activity of the enterprise, participation in various activities and physical activity of students' parents. When comparing student outcomes with regard to reporting leisure time physical activity, we should consider them optimistic that most respondents stated that they engaged in physical activity at least twice and thrice a week. Such a response with twice a week training given $(24.2 \%)$ of students, (29.1\%) of students responded that they train three times a week. As for the first answer that children never train per week we have only $1.0 \%$, this shows that young people in our country generally undertake free physical activities in their spare time. The results show that mostly Cohen kids spend their free time: listening to music, watching TV, reading books, playing with friends, meeting friends, it is interesting that in some questions we have (0) answers given as : play instruments, sing in the choir, go to concerts, and we also only have (3) answers that: they do nothing in their spare time. These answers may have been influenced by living conditions, unsatisfactory level of financial status in the family, cultures, etc. From a study conducted by (Pawelec \& Kurzak , 2013) among high school students in Warsaw, shows that high school students in Warsaw prefer a sedentary lifestyle every day as well as on weekends. This may be due to their stated interest in movies, serials and various computer games. The way you spend your leisure time in the weekend reflects the lifestyle of modern families. The most common leisure time weekend favorites are related to friends and family meetings. The leisure-time habits associated with physical activity are characteristic of only high school fourth-year students in Warsaw. The results of the research correspond 
to the results of studies conducted among young people by (Skawiński, Zaworska, Sikora, Horecka, \& Szpringer, 2011) who noted that young people spend most of their free time in front of a computer or TV. Similar conclusions were also drawn (Oblecińska \& Woynarowska , 2006) in large population studies. Also, according to a study conducted by (Bajurna \& Jakubek , 2008) in Poland activities for upper secondary students are mainly different forms of physical activity, but also thematic activities. In these tests, young people's motor activity was rated as moderate. Research results show that the most common forms of leisure time are that students mostly listen to music, meet friends, play with friends, read books, and watch TV, videos. The obvious reason for this may be the lack of access to different equipment to deal with different sports activities. It can be assumed that further economic development will result in an increase in the proportion of young people choosing different forms of leisure time. Among the forms of activities not taken by lower secondary school students from Kosovo are: skate-rolling, aerobics, skateboarding and skating, those forms can be classified as "expensive"; these devices are not available at all clubs, sports halls etc. On the other hand, a higher percentage of respondents compared to other activities was that (123) students in their spare time read books, (112) students meet friends, (116) students indicated that they spend free time playing with friends, (189) students watching TV or videos, while (290) students responding that they spend their free time listening to music. It is interesting in contrast to their peers in some countries in the European Union that 58 students in their spare time do family visits, compared to children from some European Union countries who have a much lower percentage of family visits (Glapa, Bronikowski, Górka, \& Morina, 2013). The effectiveness of (and not only) health education requires a reconciliation between the health education delivered in schools and the student experience in the family. Family has an important impact on the development of lifestyle and health behavior. It has been shown that this support is useful in terms of building good health habits. (Wojciechowska, Mojs , \& Stanisławska , 2008). In the research, students were asked about their parents if they received any activities (especially mothers and fathers). In the case of mothers, responses were split between not doing at all and doing sometimes, it is worth noting that (38.5\%) of the respondents responded that their mothers never do any form of physical activity, whereas (48.2\%) of the respondents answered that sometimes they do physical activities. On the other hand, in the case of fathers, physical activity was better assessed. A large number of respondents $(27.4 \%)$ responded that fathers regularly engage in physical activity, while $(53.5 \%)$ responded that their parents sometimes engage in physical activity. This situation can be caused by different division of family duties and generally different perception of the traditional role of a man, the head of the family in our country, different socio-cultural and religious conditions. The need for action on youth health is highlighted in important international documents that reiterate many common recommendations on the need to improve the health care system, promote healthy lifestyles, improve life skills as a modern strategy for preventing many disorders. An important idea is to enable young people to prioritize and create programs for the benefit of their health (West \& Sweeting, 2004). It seems that in our country this is difficult to achieve at the present stage of the development of education systems and often highly authoritarian educational traditions. Hopefully, success will increase by introducing into the nuclear curriculum the need to define some solutions and educational plans together with students. Creating social inequality can contribute to the overall improvement of public health and to selected age groups. The relationship between social factors and adolescent health is complex. Making conclusions about differences depends on the accepted health and social factors. It is believed that during adolescence health differences do not show as strongly as in early childhood and adulthood (Sińczuch, 2009). The reason for this is the smaller impact of factors related to family life, and greater than those related to a common group. This research shows that the level of wealth (not very high both in family and in the whole country) can have an impact on the choice of activities undertaken by young people. Undoubtedly, socio-cultural factors and the tradition of social life also have a great influence and influence the way of spending free time (as can be seen especially in the case of the tested ones in our country).

\section{Conclusion}

In line with the individual research objectives and hypotheses, the results show that: In some cases, the presented hypotheses have been validated, and in some cases they have been rejected. As for Running in this case we reject the 0 hypothesis and accept the alternative. Thus, we find that there is a statistically significant difference in this activity of children in urban and rural areas. Swimming also rejects the 0 hypothesis and accepts the alternative. Thus, we find that there is a statistically significant difference in this activity of children in urban and rural areas. In the case of Biking we reject the 0 hypothesis and accept the alternative. So, we find that there is a statistically significant difference in cycling during children's leisure time in urban and rural areas. In the case of Basketball we accept the 0 hypothesis and reject the alternative. Thus, we conclude that there is no statistically significant difference between residence and playing basketball as a leisure time activity of children in urban and rural areas. In 
the case of Volleyball we accept the null hypothesis and reject the alternative. Thus, we conclude that there is no statistically significant difference between residence and playing volleyball as physical activity during leisure time in urban and rural areas. In this case of Soccer, we reject the 0 hypothesis and accept the alternative. Thus, we find that there is a statistically significant difference in this activity of children in urban and rural areas. In the case of Handball we reject the 0 hypothesis and accept the alternative. Thus, we find that there is a statistically significant difference between residence and playing handball as physical activity during leisure time in urban and rural areas. In the case of Aerobic we reject the 0 hypothesis and accept the alternative. Thus, we conclude that there is a statistically significant difference between residence and aerobics as physical activity during leisure time in urban and rural areas. In the case of Weight-lifting we reject the 0 hypothesis and accept the alternative. Thus, we conclude that there is a statistically significant difference between residence and weight-lifting as a physical activity during leisure time in urban and rural areas.

Overcoming social inequality can contribute to the overall improvement of the health of students of selected age groups. The relationship between social factors and adolescent health is complex. It is believed that during adolescence health differences do not show as strongly as in early childhood and adulthood (Sińczuch, 2009). The reason for this is the smaller impact of factors related to family life, and greater than those related to a common group. Research shows that the level of wealth (not very satisfying for the family, but for the whole country) can have an impact on the choice of activities undertaken by young people. Admittedly, socio-cultural factors and the tradition of social life also have a great impact and set certain ways of spending time (as can be seen in our research). The above observations, the future taking into account local conditions, should be a starting point for those planning changes in physical education systems in our country.

\section{REFERENCES}

1. Bajurna, B., \& Jakubek, E. (2008). Zachowania zdrowotne młodzieży w aspekcie umiejętności spędzania wolnego czasu W: Szanse i bariery w ochronie zdrowia. Poznań: Wybrane aspekty organizacyjne, prawne, psychologiczne [red.] Głowacka, E. Mojs.

2. Dąbrowski, Z. (1966). Czas wolny dzieci i młodzieży. Warszawa: Państwowe Zakłady Wydawnictw Szkolnych, PZWS.

3. Dumazedier J. (1956). Rzeczywistość czasu wolnego a ideologia. Nowoczesna Kultura, 36:56.

4. Glapa, A., Bronikowski, M., Górka, J., \& Morina, B. (2013). Journal of Physical Education \& Health, 3342.Leisure Time Activities Among Young People Aged 13-16 From Kosovo, Bulgaria And Poland.

5. Nowak-Starz G. (2008). Rozwój i zagrożenia zdrowia populacji w wieku rozwojowym w okresie przemian społeczno-ekonomicznych w Polsce. Kielce: Wszechnica Świętokrzyska.

6. Oblecińska, A., \& Woynarowska , B. (2006). Zdrowie subiektywne, zadowolenie z życia i zachowania zdrowotne uczniów szkół ponadgimnazjalnych w Polsce. Warszawa, Wydawnictwo Ezdorant: Instytut Matki i Dziecka.

7. Pawelec , K., \& Kurzak , M. (2013). Zachowania zdrowotne warszawskich gimnazjalistów. Zeszyty Naukowe WSKFiT.

8. Sińczuch, M. (2009). Polityka młodzieżowa jako odrębny obszar działania Unii Europejskiej W: Polityka młodzieżowa. [red.] Zielińska G. $147-172$.

9. Skawiński, D., Zaworska, W. A., Sikora, D., Horecka, L. A., \& Szpringer, M. (2011). Ocena poziomu wiedzy z zakresu profilaktyki wad postawy wśród dzieci i młodzieży. Studia Medyczne.

10. Telama, R; Naul, Roland; Nupponen, H; Rychtecky, A; Vuolle, P;. (2002). Physical Fitness, Sporting Lifestyles and Olympic Ideals: Cross-Cultural Studies on Youth Sport in Europe. vol. 11 of Sport Science Studies. UNIVERSITÄT DUISBURG-ESSEN: Hofmann.

11. The child's leisure time. (n.d.). This site contains information about the Swedish society and is run by the County Administrative Boards of Sweden: information om sverige.

12. Umiastowska, D. (1999). Styl życia, wiedza o olimpizmie i sprawność fizyczna szczecińskich uczniów. Wydawnictwo Naukowe Uniwersytetu Szczecińskiego.

13. West, P., \& Sweeting, H. (2004). Evidence on equalization in health in youth from the West of Scotland. 59:13-27.

14. Wojciechowska, J., Mojs , E., \& Stanisławska , K. (2008). Regulacyjne właściwości programów prewencji otyłości u dzieci i młodzieży a środowiskowe czynniki ryzyka (Vol. 4). Pielęgniarstwo Polski. 